\title{
Roles of Eph/ephrin bidirectional signaling in central nervous system injury and recovery (Review)
}

\author{
JIN-SHAN YANG, HUI-XING WEI, PING-PING CHEN and GANG WU \\ Department of Neurology, The First Affiliated Hospital of Fujian Medical University, Fuzhou, Fujian 350000, P.R. China
}

Received July 4, 2017; Accepted October 26, 2017

DOI: $10.3892 /$ etm.2018.5702

\begin{abstract}
Multiple cellular components are involved in the complex pathological process following central nervous system (CNS) injury, including neurons, glial cells and endothelial cells. Previous studies and neurotherapeutic clinical trials have assessed the molecular mechanisms that underlie neuronal cell death following CNS injury. However, this approach has largely failed to reduce CNS damage or improve the functional recovery of patients. Erythropoietin-producing human hepatocellular (Eph) receptors and ephrin ligands have attracted considerable attention since their discovery, due to their extensive distribution and unique bidirectional signaling between astrocytes and neurons. Previous studies have investigated the roles of Eph/ephrin bidirectional signaling in the developing central nervous system. It was determined that Eph/ephrin bidirectional signaling is expressed in various CNS regions and cell types, and that it serves diverse roles in the adult CNS. In the present review, the roles of Eph/ephrin bidirectional signaling in CNS injuries are assessed.
\end{abstract}

\section{Contents}

1. Introduction

2. Eph and ephrin structure

3. Eph/ephrin expression in the adult central nervous system (CNS)

4. Expression and regulation of Eph receptors and ephrins in the adult CNS following injury

5. Therapeutic implications in neurological disorders

6. Conclusions

Correspondence to: Dr Jin-Shan Yang, Department of Neurology, The First Affiliated Hospital of Fujian Medical University, 20 Chazhong Road, Fuzhou, Fujian 350000, P.R. China

E-mail: jinshan_yang@sina.com

Key words: erythropoietin-producing human hepatocellular/ephrin, bidirectional signaling, central nervous system, injury, recovery, neurological disorder

\section{Introduction}

Erythropoietin-producing human hepatocellular(Eph) proteins constitute the largest known receptor tyrosine kinase family, and the first identified was the EphA1 receptor in 1987 (1). The Eph receptor family comprises 14 members in humans and other mammals and is divided into two subfamilies based on sequence conservation and ligand binding affinity: EphA (EphA1-EphA8 and EphA10) and EphB (EphB1-EphB4 and EphB6) (2). Eph receptors are activated when bound to membrane-combined ephrin ligands. A total of nine EphA receptors preferentially bind to five glycosylphosphatidylinositol-anchored ephrin-A ligands (ephrin-A1-A5). In addition, five EphB receptors possess high-affinity binding domains to three transmembrane ephrin-B (ephrin-B1-B3) ligands. EphA4 and EphB2 are exceptions, which can bind to both A-type and most B-type ligands (2). The formation of the Eph/ephrin complex initiates bidirectional signaling, which acts upon Eph-expressing and ephrin-expressing cells. Signaling pathways that are directly initiated by Eph receptors and ephrin ligand activations are termed forward signaling and reverse signaling, respectively (3). Previous studies have reported the diverse roles of Eph/ephrin bidirectional signaling in pathological and physiological processes (4-7).

\section{Eph and ephrin structure}

Eph structure. Eph receptors exhibit similar structural characteristics, despite the large number of subtypes. The extracellular region of Eph receptors is primarily comprised of a highly-conserved N-terminal globular domain, which is essential for ephrin identification and binding (8). Following on from the globular domain, the Eph extracellular region also includes one unique cysteine-rich and two fibronectin type III motifs, which affect receptor dimerization $(8,9)$. The intracellular region of Eph contains four structural and functional units: A juxtamembrane region, a conserved kinase domain, a sterile-a-motif (SAM) domain and a PSD95/Dlg/ZO1 (PDZ)-binding motif. The juxtamembrane region is a highly conserved motif containing two tyrosine residues, which are the primary autophosphorylation sites for downstream signal transduction $(10,11)$. The conserved tyrosine kinase domain is involved in the binding and activating of small guanosine 5'-triphosphate (GTP)ases, which are important for the regulation of the cytoskeletal structure (12). The SAM domain 
is located in the carboxyl-terminal tail of Eph receptors. It is a conserved region containing 60-70 amino acids, which regulates receptor dimerization and initiates downstream signal transduction $(13,14)$. The postsynaptic density of the protein zona occludens PDZ-binding domain is critical for the assembly and localization of the Eph/ephrin complex (15).

Ephrin structure. Ephrin ligands are divided into two subfamilies based on sequence conservation and their respective affinities for Eph receptors; ephrin-A and ephrin-B. Ephrin-A ligands (ephrin-A1-A5) possess a GPI-anchor that attaches ephrin-A to the membrane at the carboxyl terminal. Ephrin-B ligands (ephrin-B1-B3) possess a single transmembrane domain and a highly conserved carboxyl terminal tail, containing five tyrosine phosphorylation sites and a carboxyl-terminal PDZ-domain binding motif that is the structural basis for downstream signal transduction $(4,16)$.

Eph/ephrin complex formation and bidirectional signaling. A unique feature of the Eph/ephrin complex is that it initiates bidirectional signaling following its formation; the Eph receptor may act as a ligand and the ephrin ligand may act as a receptor (17). Forward and reverse signaling is involved in numerous physiological processes, including cell migration, axonal outgrowth, axonal pathfinding, topographic mapping, axon fasciculation and vascular formation in the developing nervous system $(18,19)$.

The initiation of Eph/ephrin bidirectional signaling requires the formation of highly clustered Eph/ephrin complexes. Previous studies have demonstrated that recombinant soluble ephrin must be pretreated to form clusters and induce Eph receptor phosphorylation and downstream signaling $(20,21)$. Soluble monomeric ephrins act as Eph receptor antagonists instead of Eph receptor agonists $(22,23)$. Similarly, reverse signaling through ephrin ligand requires interactions with clustered Eph receptors $(24,25)$. The blocking functions of soluble monomeric ephrin or Eph extracellular domain (ECD) may therefore provide a potential tool for the manipulation of bidirectional signaling (26).

Eph forward signaling induced by ephrin binding initiates downstream signal transduction following the autophosphorylation of two conserved tyrosine residues in the juxtamembrane region (27). Downstream pathways of Eph forward signaling have been studied extensively $(15,17,27-36)$. Eph receptor-mediated forward signaling modulates the dynamic rearrangement of the cytoskeleton and is involved in cellular remodeling, serving a role in certain regenerative processes, including neurite outgrowth and cell migration (37). Previous studies have demonstrated that Eph receptors are highly specific to Rac, cell division control protein 42 (Cdc42), Rho and small GTPases, which are critical for the regulation of the actin cytoskeleton $(37,38)$. Eph receptor forward signaling inhibits axonal regeneration in neurons by stimulating growth cone collapse through Rac and Cdc42 (37,39-41). In contrast, the blocking of Eph receptors stimulates the activation of downstream Rac and Cdc42, promoting axonal outgrowth (42). Therefore, EphA receptor signaling may also provide repulsive guidance for growing axons via the activation of Rho. It has been demonstrated that Rac and Cdc42 activation promote axonal outgrowth in the absence of Eph forward signaling $(31,42,43)$.
Notably, EphB1/EphB2/EphB3 triple knockout mice had long, thin and immature neural spines compared with wild-type mice, suggesting that ephrin-B/EphB signaling promotes spine formation and maturation (44). Ephexin is a novel member of the diffuse B cell lymphoma-like family of guanine nucleotide exchange factors. It functions to link EphA4 receptors to Rho GTPases, which serve vital roles in axon guidance $(31,43)$. It has been demonstrated that ephrin-A3 acts via EphA4 to suppress Wnt/ $\beta$-catenin signaling to inhibit the neurogenic potential of retinal stem cells (45). Eph forward signaling may also be involved in the mitogen-activated protein kinase, phosphoinositide 3-kinase (PI3K) and Janus kinase/signal transducer and activator of transcription (STAT) pathways (46-48).

Ephrin signal conduction into its host cell is defined as reverse signaling. Previous studies have revealed that ephrin reverse signaling is involved in neural progenitor proliferation (49), axon guidance (50), neuronal migration (51) and synaptic plasticity (50). However, the intracellular signaling cascades that are initiated following ephrin activation remain unknown. Ephrin-As lack a cytoplasmic tail; however, they are capable of activating downstream Src family kinases (SFKs) and PI3K with the aid of co-receptors $(52,53)$. It was demonstrated that associated transmembrane signaling partners, including topomyosin receptor kinase B and p75 neurotrophin receptor, may act as co-receptors for ephrin-As (54).

Ephrin-B ligands are composed of a single transmembrane region and a short, highly conserved cytoplasmic domain with a carboxy-terminal PDZ domain-binding motif. Together, these constitute the structural foundation required for reverse signaling (55). The activation of ephrin-B ligands leads to the recruitment of SFKs, which phosphorylate tyrosine residues located in the cytoplasmic domain. Previous research has revealed that Src-homology-2-domain-containing adaptor molecules, such as Grb4, are recruited and phosphorylated by ephrin-B, which further initiates downstream signaling and regulates cytoskeletal dynamics (56-60). The basophil-like protein tyrosine phosphatase is also recruited via its PDZ domain to the carboxy-terminal tail of ephrin-B, leading to its dephosphorylation and the inactivation of SFKs. This inactivation acts as a switch from phosphotyrosine-dependent to PDZ-domain-dependent signaling (61). PDZ regulation of G-protein signaling 3 may inhibit C-X-C chemokine receptor type 4-mediated chemoattraction by inhibiting the $\mathrm{G} \alpha \beta \gamma$-protein complex, which further regulates the migration of endothelial cells and angiogenesis $(62,63)$ (Fig. 1).

\section{Eph/ephrin expression in the adult central nervous system (CNS)}

Previous studies have assessed the role Eph in the developing CNS. The expression of Eph receptors and ephrin ligands changes markedly during CNS development (19). Ephs and ephrins continue to be expressed in the adult CNS and are distributed in most regions and types of cell (6). Various Eph receptors and ephrins continue to be highly expressed in adult brain regions that possess morphological and physiological plasticity, including the amygdala and hippocampus (64).

Previous studies have elucidated the diverse roles of Eph receptors and their ephrin ligands in the adult CNS. Eph receptors and their ligands serve primary roles in the regulation 


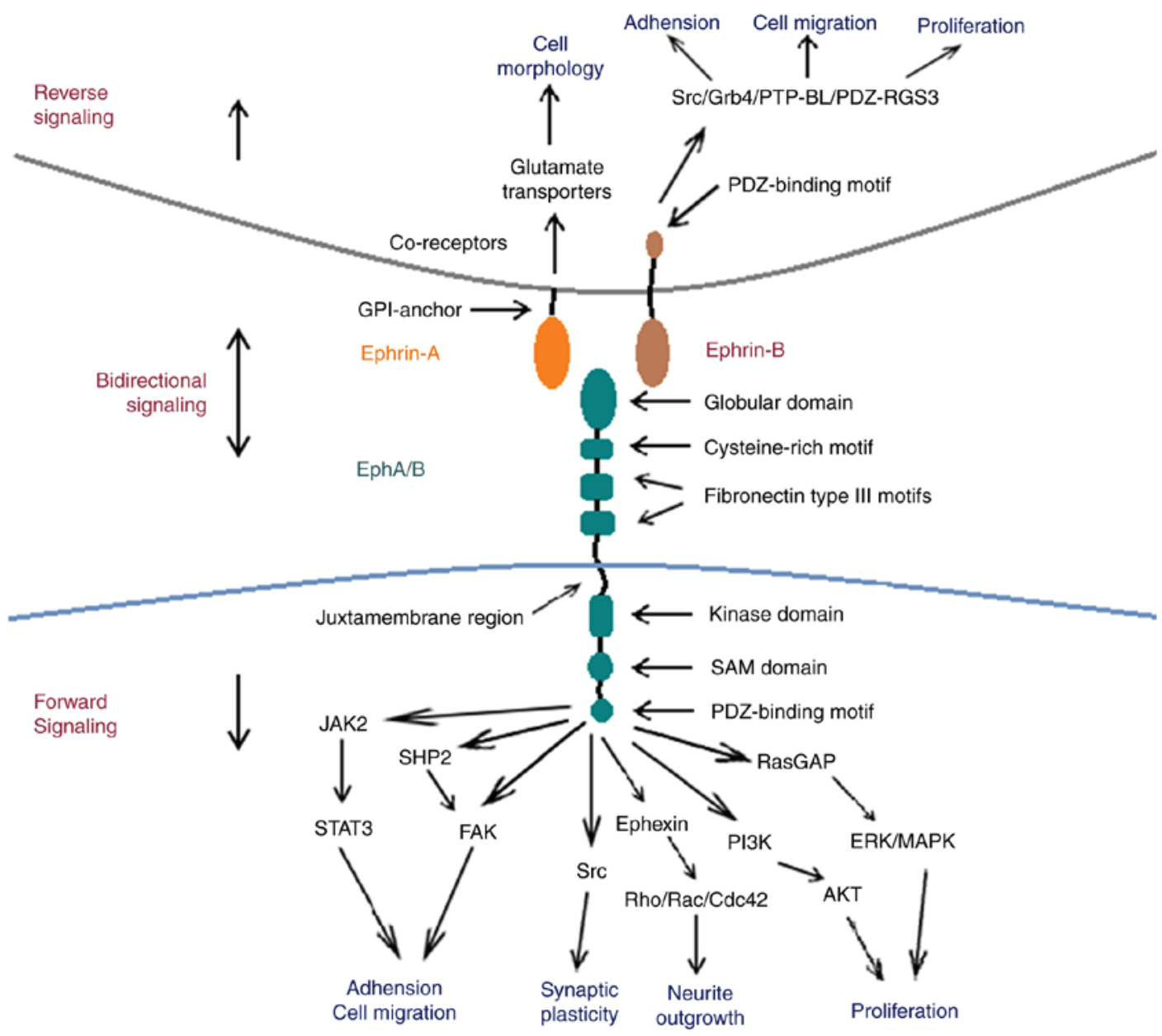

Figure 1. Schematic representation of Eph/ephrin structures and signaling pathways. Eph receptors are comprised of an ephrin-binding globular domain, a cysteine-rich region, two fibronectin type III domains, a juxtamembrane region, a kinase domain, a SAM domain and a PDZ-binding motif. Ephrin-As are attached to the cell membrane via a GPI-anchor, and ephrin-Bs are transmembrane proteins with a cytoplasmic tail and a terminal PDZ-binding motif. Activated Eph/ephrin bidirectional signaling initiates multiple different pathways involved in the regulation of synaptic plasticity, cell morphology, neurite outgrowth, cell migration, adhesion and proliferation. Eph, erythropoietin-producing human hepatocellular receptor; SAM, sterile-a-motif; PDZ, PSD95/Dlg/ZO1; GPI, glycosyl-phosphatidylinositol; RasGAP, Ras GTPase activating protein; ERK, extracellular signal-related kinase; MAPK, mitogen-activated protein kinase; PI3K, phosphoinositide 3-kinase; Cdc42, cell division control protein 42; FAK, focal adhesion kinase; JAK2, Janus kinase 2; STAT3, signal transducer and activator of transcription 3 .

of synapse formation, function and plasticity $(33,65,66)$, which is particularly important in the maintenance of hippocampal plasticity (67) and the processing of certain types of pain (68). Previous studies have demonstrated that the activation of EphA4 forward signaling mediates the retraction of dendritic spines and reduces their number and size by remodeling the actin cytoskeleton and modifying the properties of adhesion receptors $(35,69,70)$. It has also been demonstrated that EphA4 blockade leads to significantly longer and overlapping dendritic spines (71). However, contrasting effects were observed in triple EphB (EphB1/EphB2/EphB3) knockout mice. A significant decrease in dendritic spine density and the formation of headless or small-headed spines were observed, suggesting that EphB forward signaling is responsible for dendritic spine formation and synaptic maturation $(44,72)$. Previous studies have also compared Eph/ephrin knockout with wild-type mice and demonstrated that pre- and post-synaptic Eph/ephrins affect memory and learning by controlling synaptic formation $(67,73,74)$. Eph/ephrins may recruit cell surface molecules, such as the N-methyl-D-aspartate receptor (NMDAR), via their PDZ domain $(75,76)$. EphB2 forward signaling and ephrin-B3 reverse signaling also induces the generation of long-term potentiation (LTP) via NMDARs $(33,50,77-80)$.

EphA4/ephrin-A3-mediated bidirectional signaling between neurons and astrocytes was implicated in the alteration of the $\alpha$-amino-3-hydroxy-5-methyl-4-isoxazolepropionic acid receptor and spine morphology in the hippocampus (67). In addition, Eph4A forward signaling and glial ephrin-A3 reverse signaling regulates the astrocyte glutamate transporter and the plasticity of synapses within the hippocampus, respectively $(81,82)$. Furthermore, ephrin-Bs/EphB participate in the processing of spinal cord pain via the NMDAR, PI3K and downstream signaling pathways (83-87).

Ephs and their ephrin ligands are also expressed in the subventricular zone (SVZ) of the lateral ventricle and subgranular zone (SGZ) of the dentate gyrus, where neural stem cells maintain neurogenesis throughout the lifetime of mammals (88). Eph/ephrin bidirectional signaling influences the proliferation and differentiation of neural precursor cells (NPCs) (89). Previous studies have demonstrated that EphB3/ephrin-B3 regulates the proliferation and differentiation of cells in the SVZ 
and the rostral migratory stream (RMS) through altering the expression of p53 (90-93). In addition, EphA4 knockout mice exhibit decreased cell proliferation and differentiation disorder in the SVZ and RMS, resulting in a reduced number of neuroblasts (94). It has been demonstrated that EphB1/ephrin-B3 signaling also affects the proliferation and differentiation of NPCs in the SGZ of the dentate gyrus, highlighting a potential therapeutic target for neurodegenerative diseases and brain damage (7). In addition, the interactions between neural stem cells and blood vessels in the SVZ function to regulate quiescence and promote stemness. In particular, ephrin-B2 presented by vascular endothelial cells suppresses the proliferation and differentiation of stem cells through the activation of their respective Eph receptors and downstream notch signaling pathways. Ephrin-B2/Eph and notch signaling is suspended as stem cells detach from blood vessels to differentiate and divide (95).

$\mathrm{Eph} / \mathrm{ephrin}$ signal transduction is involved in CNS angiogenesis. It has been demonstrated that EphA2 receptor blockade improves the formation of tight junctions between endothelial cells and promotes angiogenesis (96). In addition, an intracerebroventricular injection of ephrin-A1 may promote angiogenesis by stimulating EphA forward signaling (26). Small competitive Eph-ephrin antagonists have also been demonstrated to disrupt the interaction between EphA2 and ephrin-A1, blocking angiogenesis at low micromolar concentrations (97). A previous study also revealed that ephrin-A1 was involved in the modulation of the actin cytoskeleton, demonstrating its vital role in re-endothelialization (98).

\section{Expression and regulation of Eph receptors and ephrins in the adult CNS following injury}

Eph/ephrin signaling is also involved in sophisticated pathological processes following CNS injury. Eph receptors and ephrin ligands are upregulated following CNS injury and exhibit diverse changes depending on the location or time at which injuries occur (99-103). Certain types of cell behave differently following CNS damage: Neurons attempt to regenerate damaged connections; astrocytes and microglial cells proliferate, migrate and become activated to maintain homeostasis; and oligodendrocytes initiate remyelination (104). The alteration of Eph and ephrin expression under these situations may reveal the function of Eph/ephrin signaling in the damage response. Ephs and ephrins may regulate axon guidance in the developing CNS and so may serve a similar role during CNS regeneration (105). Eph receptors and their ephrin ligands are also expressed in mature cell types, including neurons and astrocytes. They may therefore exhibit different effects compared with those observed in CNS development, including the mediation of astrocytic gliosis, neural regeneration, vascular remodeling and neuroinflammation (106).

Eph/ephrin signaling affects glial scar formation and glutamate homeostasis. Eph receptors and their ephrin ligands may influence the structural and functional reorganization of the CNS during trauma. Ephs and ephrins may respond to CNS injury by promoting the formation of glial scars due to their inhibitory effect on axonal regeneration (105). Previous results have revealed that the sophisticated processes involving gliosis include glial reactivation, extracellular matrix alteration and collagen deposition (107). Multi-cellular components including astrocytes, microglia, oligodendrocyte progenitors and fibroblasts participate in the formation of glial scars (108-110). Ephs and ephrins are expressed in many types of cells associated with gliosis and glial scars and affect their response to damage. Glial cells trigger gliosis in CNS injury as they are highly sensitive to damage (111). Gliosis is a process that begins with glial cell activation and proliferation, and is characterized by morphological and functional changes in astrocytes and microglia. Astrocytic activation results in cellular hypertrophy, proliferation and gliosis (112), which are observed in areas distal to the site of injury $(113,114)$. However, the astro-glial response has positive and negative effects on neuronal cell recovery and degeneration. There are various benefits of glial scar formation, including the separation of the site of injury from surrounding normal tissues, thus reducing the spread of damage and filling of the lesion cavity (115-117). Glial scars help to reconstruct damaged brain areas and re-organize blood vessels following epithelial cell invasion into the scar tissue. Previous studies have demonstrated that glial scars also act as primary barriers to neural regeneration $(35,118,119)$. There is mounting evidence that Eph/ephrin signaling is involved in glial scar formation in CNS disorders. It has been demonstrated in a model of spinal cord injury, that the development of glial scars and the exclusion of meningeal fibroblasts from the site of damage are a result of cell contact-mediated bidirectional signaling cascades, stimulated by the interaction of ephrin-B2 and EphB2 with reactive astrocytes and meningeal fibroblasts, respectively (103). Another previous study demonstrated that ephrin B2 (-/-) mice exhibited a reduction in astrogliosis and an accelerated regeneration of injured corticospinal axons, which resulted in the recovery of murine motor function following spinal cord injury (SCI) (105). It was also demonstrated that astrocytic gliosis and glial scars were greatly reduced in lesioned EphA4 $4^{-/}$spinal cords. EphA4 ${ }^{-/}$astrocytes also failed to respond to inflammatory cytokines, including interferon- $\gamma$ and leukemia inhibitory factor in vitro (35). In addition, neurons grown in wild-type astrocytes exhibited shorter neurites compared with neurons grown in EphA4 $4^{--}$astrocytes (120). Previous studies have demonstrated that the use of EphA4 inhibitors moderately reduced astrocytic gliosis, promoted axonal regeneration and improved functional outcome following spinal cord hemisection in wild-type mice $(35,121)$.

Glutamate is the primary excitatory neurotransmitter in the CNS; however, it is also a potential neurotoxin as excessive glutamate signaling may lead to excitotoxic cell death (122). The maintenance of extracellular glutamate homeostasis is a supportive function of astrocytes that occurs during brain injury, the function of which may be regulated by Eph/ephrin signaling. The use of clustered EphA4 was demonstrated to decrease the expression of astrocyte glutamate transporters and the glutamate uptake capacity of astrocytes via the activation of ephrin-A3 reverse signaling (123). These results indicated that EphA4-mediated ephrin-A3 reverse signaling is a vital mechanism for astrocytes to control glial glutamate transporters and prevent glutamate excitotoxicity under pathological conditions (123). A novel role of ephrin-B1 was determined in astrocyte-mediated synapse remodeling following traumatic brain injury (TBI). The upregulation of astrocytic ephrin-B1 following injury reduced the vesicular glutamate transporter 1 
positive excitatory presynaptic innervation of CA1 neurons via STAT3-mediated signaling in astrocytes (124). Therefore, the regulation of ephrin-B1 signaling in astrocytes may provide novel therapeutic opportunities to aid glutamate homeostasis and functional recovery following TBI (124).

Eph/ephrin signaling mediates neurogenesis and angiogenesis. Endogenous NPCs are present in the SGZ of the dentate gyrus and in the rostral SVZ of the lateral ventricles in the mature CNS (125). NPC proliferation in the SVZ and SGZ is triggered under pathophysiological conditions. These neuroblasts may migrate to the lesion area and differentiate into neurons to replace those that are damaged $(126,127)$.

Eph/ephrin bidirectional signaling influences the proliferation and differentiation of NPCs, affecting their response to CNS injury. EphB3/ephrin-B3 regulates the proliferation and differentiation of cells in the SVZ and the RMS by controlling p53 levels (90-93). Post-ischemic neurogenesis in ephrin-B3 (-/-) mice was strongly enhanced and associated with the caspase-3-dependent activation of STAT1 (128). EphB2 has been demonstrated to control the migration of dentate progenitor cells into the dorsal half of the developing dentate gyms (129). A previous study revealed that blockade of EphB2 enhanced neurogenesis in the SVZ and improved neurological function following cerebral cortical infarction in hypertensive rats (130). Neurons adapt their structure and function to microenvironmental changes by controlling neural plasticity. Previous studies have demonstrated that Eph/ephrin signaling exhibits an inhibitory effect on neurite outgrowth in CNS damage (131-133). For example, ephrin-A5 reverse signaling induces growth cone collapse and inhibits axonal regeneration by activating RhoA or dependent protein kinases (131). Ephrin-A5-mediated EphA4 forward signaling also triggers axonal growth cone collapse via the downstream Rac GTPase-activating protein $\alpha 2$-chimera-independent signaling pathway (132). The intervention of ephrin-A5/EphA4 communication may therefore serve a vital role in the suppression of neuron generation through the phosphorylated (p)-Akt and p-extracellular signal-related kinase (ERK) pathways (133). EphA4 targeting using miR-93 was demonstrated to promote neurite outgrowth in spinal cord injury in rats following a reduction in p-Ephexin and active RhoA levels (134).

Eph/ephrin bidirectional signaling regulates oligodendrocyte precursor cells (OPCs) and oligodendrocytes. Eph-ephrin interactions between axons and OPCs may control the distribution of OPCs in the optic axonal tracts and the cessation of their migration (135). It was revealed that ephrin-B3 is expressed in postnatal myelinating oligodendrocytes and acts as myelin-based inhibitor through a combined p75 neurotrophin receptor (136). A previous study demonstrated that EphB3 functions as a dependence receptor that mediates oligodendrocyte cell death following SCI, which further supports the development of ephrin-B3 based therapies to promote recovery (137).

It is now relatively well accepted that neurogenesis and angiogenesis are coupled processes. Eph receptors and their ephrin ligands are also involved in angiogenesis, which is critical for the remodeling of vasculature following CNS injury (138). EphA2 is an essential regulator of post-natal angiogenesis. The stimulation of ephrin-A 1 induces the PI3K-dependent activation of Ras-related C3 botulinum toxin 1
(Rac1) in wild-type endothelial cells, and EphA2-deficient cells fail to activate Rac1 upon stimulation. EphA2-deficient endothelial cells fail to undergo vascular assembly and migration in response to ephrin-A1 in vitro (139). The competitive small molecule UniPR129 acts as an Eph/ephrin antagonist and blocks angiogenesis at low concentrations in vitro (140). It has been suggested that increasing ephrin-B2 levels may promote vascular endothelial growth factor (VEGF)-induced VEGF receptor 2 endocytosis and the angiogenic function of endothelial cells (141). Previous studies have demonstrated that the ephrin-A5/EphA4 interaction mediates the ERK and Akt signaling pathways in pilocarpine-induced epilepsy, and that the intervention of ephrin/Eph interactions suppresses newborn neuron generation and microvessel remodeling in a mouse model of temporal lobe epilepsy $(142,143)$.

Eph/ephrin signaling and neuroinflammation. Post-injury inflammation is implicated in most types of CNS injury. Neurodegeneration, trauma and ischemia stimulate an inflammatory response that causes microglial activation and circulating immune cell infiltration in the brain (144). Inflammation is generally considered to be beneficial for the clearance of debris formed by necrotic cells. However, severe inflammation causes cerebral swelling and vascular dysfunction, which exaggerates neuronal damage (144). Previous studies have indicated that Eph/ephrin proteins are involved in the inflammatory process following CNS injury. EphA2 and ephrin-A1 serve roles in the maintenance of endothelial junction integrity and cytoskeletal structure, potentially in response to the upregulation of inflammatory mediators, resulting in vascular leakage $(145,146)$. EphA2 inactivation promotes the formation of tight junctions in the endothelial cells of the brain (96). There is also considerable interest in ephrin-B2/EphB4 signaling. Ephrin-B2 is a marker of arterial endothelial cells in the vasculature and EphB4, one of its cognate receptors, is predominantly expressed in the venous endothelium. Endothelial ephrin-B2 primarily functions via the VEGF receptor to mediate vascular responses during inflammation (147). Therefore, therapies that inhibit the function of ephrin-B2/EphB4 may suppress the inflammatory response following injury (148). EphB receptor inhibition using EphB1-fragment crystallizable reduced formalin-induced inflammation and chronic constrictive injury-induced neuropathic pain behaviors via the control of PI3K and PI3K crosstalk to ERK signaling (87). Ephrin-B/EphB signaling also serves a primary role in the regulation of inflammatory pain via NMDAR subunit NR2B and $\mathrm{PKC} \gamma$ regulation $(76,149)$.

\section{Therapeutic implications in neurological disorders}

The underlying mechanisms of Eph/ephrin signaling remain poorly understood. The key roles of Eph/ephrin signaling in the progression of a large range of neurological disorders suggest that Ephs and ephrins may be potential therapeutic targets. Previous studies have indicated that Eph/ephrin signaling may be a suitable therapeutic target for the treatment of neurological diseases.

Alzheimer's disease $(A D)$. AD is the most common type of neurodegenerative disorder that manifests as a progressive decline in 
cognitive function. It has been demonstrated that EphB2 and EphA4 are downregulated in AD (74). Soluble amyloid- $\beta$ (A $\beta)$ peptide oligomers are derived from amyloid precursor proteins (APPs) and are a major causative agent of synaptic impairment in AD. Previous studies have suggested that $A \beta$ oligomers indirectly affect the NMDAR NR1 subunit and induce NMDAR depletion by forming a complex with EphB2 (150,151). In addition, increased EphB2 expression reverses deficits in NMDAR-dependent LTP and memory impairments in murine models of AD (152). EphA4 may also be a potential therapeutic target of $\mathrm{AD}$. It has been demonstrated that EphA4 mediates the $\mathrm{A} \beta$-induced impairment of synaptic plasticity; the depletion or blockade of postsynaptic EphA4 activity reverses synaptic deficits in murine models of AD. Rhy is a small-molecule inhibitor of EphA4 that rescues $A \beta$-induced impairments in neurotransmission and LTP in murine models of AD (153).

Amyotrophic lateral sclerosis (ALS). ALS is a neurodegenerative disease that is caused by the progressive degeneration of the upper and lower motor neurons in the anterior horn of the spinal cord, brainstem and cerebral cortex (154). The ALS8 gene leads to the development of familial ALS and accounts for 10-15\% of all ALS cases (155). The ALS8 protein vesicle-associated membrane protein-associated B (VAPB) is a ligand for EphA4. Mutations of VAPB may enhance EphA4/ephrin-A3 signaling and lead to the dysfunction of glial glutamate transporters, as observed in ALS $(81,156)$. However, the specific role of EphA4 in the pathology of ALS requires further investigation $(81,155)$.

\section{Conclusions}

The observations described in the present review provide evidence that Ephs and ephrins serve a vital role in determining the regenerative outcomes of CNS disorders. Signaling through Eph/ephrin complexes directly regulates neural regeneration by stimulating growth cone collapse, promoting glial scar formation, regulating homeostasis, reducing neurogenesis, inhibiting myelination and exaggerating inflammation together with injury-induced neuropathic pain. In addition, the interaction between Ephs and ephrin ligands is essential for angiogenesis. Therefore, the regulation of these molecules following CNS injury may serve as therapeutic targets for the treatment of various neurological diseases.

\section{Acknowledgements}

The present review was supported by the Fujian Provincial Natural Science Foundation (grant no. 2017J05123), the Startup Fund for scientific research, Fujian Medical University (grant no. 2016QH067), the National Key Clinical Specialty Discipline Construction Program (grant no. 2012-GJLCZD) and the Fujian Key Clinical Specialty Discipline Construction Program (grant no. 2012-SLCZD).

\section{References}

1. Hirai H, Maru Y, Hagiwara K, Nishida J and Takaku F: A novel putative tyrosine kinase receptor encoded by the eph gene. Science 238: 1717-1720, 1987.

2. Klein R: Bidirectional modulation of synaptic functions by Eph/ephrin signaling. Nat Neurosci 12: 15-20, 2009.
3. Aoto $J$ and Chen L: Bidirectional ephrin/Eph signaling in synaptic functions. Brain Res 1184: 72-80, 2007.

4. Flanagan JG and Vanderhaeghen P: The ephrins and Eph receptors in neural development. Annu Rev Neurosci 21: 309-345, 1998.

5. Wilkinson DG: Multiple roles of EPH receptors and ephrins in neural development. Nat Rev Neurosci 2: 155-164, 2001.

6. Goldshmit Y, McLenachan S and Turnley A: Roles of Eph receptors and ephrins in the normal and damaged adult CNS. Brain Res Rev 52: 327-345, 2006.

7. Chumley MJ, Catchpole T, Silvany RE, Kernie SG and Henkemeyer M: EphB receptors regulate stem/progenitor cell proliferation, migration, and polarity during hippocampal neurogenesis. J Neurosci 27: 13481-13490, 2007.

8. Labrador JP, Brambilla R and Klein R: The N-terminal globular domain of Eph receptors is sufficient for ligand binding and receptor signaling. EMBO J 16: 3889-3897, 1997.

9. Lackmann M, Oates AC, Dottori M, Smith FM, Do C, Power M, Kravets L and Boyd AW: Distinct subdomains of the EphA3 receptor mediate ligand binding and receptor dimerization. J Biol Chem 273: 20228-20237, 1998.

10. Bruckner K and Klein R: Signaling by Eph receptors and their ephrin ligands. Curr Opin Neurobiol 8: 375-382, 1998.

11. Holland SJ, Peles E, Pawson T and Schlessinger J: Cellcontact-dependent signalling in axon growth and guidance: Eph receptor tyrosine kinases and receptor protein tyrosine phosphatase beta. Curr Opin Neurobiol 8: 117-127, 1998.

12. Nimnual AS, Yatsula BA and Bar-Sagi D: Coupling of Ras and Rac guanosine triphosphatases through the Ras exchanger Sos. Science 279: 560-563, 1998.

13. Schultz J, Ponting CP, Hofmann K and Bork P: SAM as a protein interaction domain involved in developmental regulation. Protein science Protein Sci 6: 249-253, 1997.

14. Stapleton D, Balan I, Pawson T and Sicheri F: The crystal structure of an Eph receptor SAM domain reveals a mechanism for modular dimerization. Nat Struct Biol 6: 44-49, 1999.

15. Kullander K and Klein R: Mechanisms and functions of Eph and ephrin signalling. Nat Rev Mol Cell Biol 3: 475-486, 2002.

16. Lin D, Gish GD, Songyang Z and Pawson T: The carboxyl terminus of B class ephrins constitutes a PDZ domain binding motif. J Biol Chem 274: 3726-3733, 1999.

17. Pasquale EB: Eph receptor signalling casts a wide net on cell behaviour. Nat Rev Mol Cell Biol 6: 462-475, 2005.

18. Mellitzer G, Xu Q and Wilkinson DG: Eph receptors and ephrins restrict cell intermingling and communication. Nature 400: 77-81, 1999.

19. Klein R: Eph/ephrin signaling in morphogenesis, neural development and plasticity. Curr Opin Cell Biol 16: 580-589, 2004.

20. Davis S, Gale NW, Aldrich TH, Maisonpierre PC, Lhotak V, Pawson T, Goldfarb M and Yancopoulos GD: Ligands for EPH-related receptor tyrosine kinases that require membrane attachment or clustering for activity. Science 266: 816-819, 1994.

21. Stein E, Lane AA, Cerretti DP, Schoecklmann HO, Schroff AD, Van Etten RL and Daniel TO: Eph receptors discriminate specific ligand oligomers to determine alternative signaling complexes, attachment, and assembly responses. Genes Dev 12: 667-678, 1998.

22. Carter N, Nakamoto T, Hirai H and Hunter T: EphrinA1-induced cytoskeletal re-organization requires FAK and p130(cas). Nat Cell Biol 4: 565-573, 2002.

23. Lawrenson ID, Wimmer-Kleikamp SH, Lock P, Schoenwaelder SM, Down M, Boyd AW, Alewood PF and Lackmann M: Ephrin-A5 induces rounding, blebbing and de-adhesion of EphA3-expressing $293 \mathrm{~T}$ and melanoma cells by CrkII and Rho-mediated signalling. J Cell Sci 115: 1059-1072, 2002.

24. Cowan CA and Henkemeyer M: Ephrins in reverse, park and drive. Trends Cell Biol 12: 339-346, 2002.

25. Davy A and Soriano P: Ephrin signaling in vivo: Look both ways. Dev Dyn 232: 1-10, 2005.

26. Jing X, Miwa H, Sawada T, Nakanishi I, Kondo T, Miyajima M and Sakaguchi K: Ephrin-A1-mediated dopaminergic neurogenesis and angiogenesis in a rat model of Parkinson's disease. PLos One 7: e32019, 2012.

27. Holland SJ, Gale NW, Gish GD, Roth RA, Songyang Z, Cantley LC, Henkemeyer M, Yancopoulos GD and Pawson T: Juxtamembrane tyrosine residues couple the Eph family receptor EphB2/Nuk to specific SH2 domain proteins in neuronal cells. EMBO J 16: 3877-3888, 1997.

28. Henkemeyer M, Marengere LE, McGlade J, Olivier JP, Conlon RA, Holmyard DP, Letwin K and Pawson T: Immunolocalization of the Nuk receptor tyrosine kinase suggests roles in segmental patterning of the brain and axonogenesis. Oncogene 9: 1001-1014, 1994. 
29. Becker E, Huynh-Do U, Holland S, Pawson T, Daniel TO and Skolnik EY: Nck-interacting Ste20 kinase couples Eph receptors to c-Jun N-terminal kinase and integrin activation. Mol Cell Biol 20: 1537-1545, 2000

30. Wahl S, Barth H, Ciossek T, Aktories K and Mueller BK: Ephrin-A5 induces collapse of growth cones by activating Rho and Rho kinase. J Cell Biol 149: 263-270, 2000.

31. Shamah SM, Lin MZ, Goldberg JL, Estrach S, Sahin M, Hu L, Bazalakova M, Neve RL, Corfas G, Debant A and Greenberg ME: EphA receptors regulate growth cone dynamics through the novel guanine nucleotide exchange factor ephexin. Cell 105 : 233-244, 2001

32. Zhou X, Suh J, Cerretti DP, Zhou R and DiCicco-Bloom E: Ephrins stimulate neurite outgrowth during early cortical neurogenesis. Journal of neuroscience research 66: 1054-1063, 2001.

33. Takasu MA, Dalva MB, Zigmond RE and Greenberg ME Modulation of NMDA receptor-dependent calcium influx and gene expression through EphB receptors. Science 295: 491-495, 2002.

34. Tong J, Elowe S, Nash P and Pawson T: Manipulation of EphB2 regulatory motifs and $\mathrm{SH} 2$ binding sites switches MAPK signaling and biological activity. J Biol Chem 278: 6111-6119, 2003

35. Goldshmit Y, Galea MP, Wise G, Bartlett PF and Turnley AM Axonal regeneration and lack of astrocytic gliosis in EphA4-deficient mice. J Neurosci 24: 10064-10073, 2004.

36. Lisabeth EM, Falivelli G and Pasquale EB: Eph receptor signaling and ephrins. Cold Spring Harb Perspect Biol 5, 2013.

37. Dickson BJ: Rho GTPases in growth cone guidance. Curr Opin Neurobiol 11: 103-110, 2001

38. Giniger E: How do Rho family GTPases direct axon growth and guidance? A proposal relating signaling pathways to growth cone mechanics. Differentiation 70: 385-396, 2002.

39. Lehmann M, Fournier A, Selles-Navarro I, Dergham P, Sebok A, Leclerc N, Tigyi G and McKerracher L: Inactivation of Rho signaling pathway promotes CNS axon regeneration. J Neurosci 19: 7537-7547, 1999.

40. Dergham P, Ellezam B, Essagian C, Avedissian H, Lubell WD and McKerracher L: Rho signaling pathway targeted to promote spinal cord repair. J Neurosci 22: 6570-6577, 2002.

41. Fournier AE, Takizawa BT and Strittmatter SM: Rho kinase inhibition enhances axonal regeneration in the injured CNS J Neurosci 23: 1416-1423, 2003.

42. Nikolic M: The role of Rho GTPases and associated kinases in regulating neurite outgrowth. Int J Biochem Cell Biol 34 731-745, 2002

43. Sahin M, Greer PL, Lin MZ, Poucher H, Eberhart J, Schmidt S, Wright TM, Shamah SM, O'connell S and Cowan CW: Eph-dependent tyrosine phosphorylation of ephexin1 modulates growth cone collapse. Neuron 46: 191-204, 2005

44. Henkemeyer M, Itkis OS, Ngo M, Hickmott PW and Ethell IM: Multiple EphB receptor tyrosine kinases shape dendritic spines in the hippocampus. J Cell Biol 163: 1313-1326, 2003.

45. Fang Y, Cho KS, Tchedre K, Lee SW, Guo C, Kinouchi H, Fried S, Sun X and Chen DF: Ephrin-A3 suppresses Wnt signaling to control retinal stem cell potency. Stem Cells 31: 349-359, 2013.

46. Steinle JJ, Meininger CJ, Forough R, Wu G, Wu MH and Granger HJ: Eph B4 receptor signaling mediates endothelial cell migration and proliferation via the phosphatidylinositol 3-kinase pathway. J Biol Chem 277: 43830-43835, 2002

47. Lai KO, Chen Y, Po HM, Lok KC, Gong K and Ip NY: Identification of the Jak/Stat proteins as novel downstream targets of EphA4 signaling in muscle: implications in the regulation of acetylcholinesterase expression. J Biol Chem 279: 13383-13392, 2004

48. Macrae M, Neve RM, Rodriguez-Viciana P, Haqq C, Yeh J, Chen C, Gray JW and McCormick F: A conditional feedback loop regulates Ras activity through EphA2. Cancer Cell 8 . $111-118,2005$

49. Holmberg J, Armulik A, Senti KA, Edoff K, Spalding K Momma S, Cassidy R, Flanagan JG and Frisén J: Ephrin-A2 reverse signaling negatively regulates neural progenitor proliferation and neurogenesis. Genes Dev 19: 462-471, 2005.

50. Grunwald IC, Korte M, Adelmann G, Plueck A, Kullander K, Adams RH, Frotscher M, Bonhoeffer T and Klein R: Hippocampal plasticity requires postsynaptic ephrinBs. Nat Neurosci 7: 33-40, 2004.

51. Davy A, Aubin J and Soriano P: Ephrin-B1 forward and reverse signaling are required during mouse development. Genes Dev 18: $572-583,2004$
52. Davy A, Gale NW, Murray EW, Klinghoffer RA, Soriano P, Feuerstein $\mathrm{C}$ and Robbins SM: Compartmentalized signaling by GPI-anchored ephrin-A5 requires the Fyn tyrosine kinase to regulate cellular adhesion. Genes Dev 13: 3125-3135, 1999.

53. Davy A and Robbins SM: Ephrin-A5 modulates cell adhesion and morphology in an integrin-dependent manner. EMBO J 19: 5396-5405, 2000

54. Suetterlin P, Marler KM and Drescher U: Axonal ephrinA/EphA interactions, and the emergence of order in topographic projections. Semin Cell Dev Biol 23: 1-6, 2012.

55. Torres R, Firestein BL, Dong H, Staudinger J, Olson EN, Huganir RL, Bredt DS, Gale NW and Yancopoulos GD: PDZ proteins bind, cluster, and synaptically colocalize with Eph receptors and their ephrin ligands. Neuron 21: 1453-1463, 1998.

56. Holland SJ, Gale NW, Mbamalu G, Yancopoulos GD, Henkemeyer $\mathrm{M}$ and Pawson T: Bidirectional signalling through the EPH-family receptor Nuk and its transmembrane ligands. Nature 383: 722-725, 1996.

57. Bruckner K, Pasquale EB and Klein R: Tyrosine phosphorylation of transmembrane ligands for Eph receptors. Science 275 1640-1643, 1997.

58. Kalo MS, Yu HH and Pasquale EB: In vivo tyrosine phosphorylation sites of activated ephrin-B1 and ephB2 from neural tissue. J Biol Chem 276: 38940-38948, 2001.

59. Cowan CA and Henkemeyer M: The $\mathrm{SH} 2 / \mathrm{SH} 3$ adaptor Grb4 transduces B-ephrin reverse signals. Nature 413: 174-179, 2001.

60. Palmer A, Zimmer M, Erdmann KS, Eulenburg V, Porthin A, Heumann R, Deutsch U and Klein R: EphrinB phosphorylation and reverse signaling: Regulation by Src kinases and PTP-BL phosphatase. Mol Cell 9: 725-737, 2002.

61. Hsueh YP and Sheng M: Eph receptors, ephrins, and PDZs gather in neuronal synapses. Neuron 21: 1227-1229, 1998

62. Salcedo R, Wasserman K, Young HA, Grimm MC, Howard OM Anver MR, Kleinman HK, Murphy WJ and Oppenheim JJ: Vascular endothelial growth factor and basic fibroblast growth factor induce expression of CXCR4 on human endothelial cells: In vivo neovascularization induced by stromal-derived factor-1alpha. Am J Pathol 154: 1125-1135, 1999.

63. Lu Q, Sun EE, Klein RS and Flanagan JG: Ephrin-B reverse signaling is mediated by a novel PDZ-RGS protein and selectively inhibits $\mathrm{G}$ protein-coupled chemoattraction. Cell 105: 69-79, 2001

64. Liebl DJ, Morris CJ, Henkemeyer M and Parada LF: mRNA expression of ephrins and Eph receptor tyrosine kinases in the neonatal and adult mouse central nervous system. J Neurosci Res 71: 7-22, 2003

65. Murai KK and Pasquale EB: Can Eph receptors stimulate the mind? Neuron 33: 159-162, 2002

66. Hruska M and Dalva MB: Ephrin regulation of synapse formation, function and plasticity. Mol Cell Neurosci 50: 35-44, 2012.

67. Murai KK, Nguyen LN, Irie F, Yamaguchi Y and Pasquale EB: Control of hippocampal dendritic spine morphology through ephrin-A3/EphA4 signaling. Nat Neurosci 6: 153-160, 2003.

68. Vasileiou I, Adamakis I, Patsouris E and Theocharis S: Ephrins and pain. Expert Opin Ther Targets 17: 879-887, 2013.

69. Bouvier D, Corera AT, Tremblay ME, Riad M, Chagnon M, Murai KK, Pasquale EB, Fon EA and Doucet G: Pre-synaptic and post-synaptic localization of EphA4 and EphB2 in adult mouse forebrain. J Neurochem 106: 682-695, 2008.

70. McKinnell IW, Makarenkova H, de Curtis I, Turmaine M and Patel K: EphA4, RhoB and the molecular development of feather buds are maintained by the integrity of the actin cytoskeleton. Dev Biol 270: 94-105, 2004.

71. Heintz TG, Eva R and Fawcett JW: Regional regulation of purkinje cell dendritic spines by integrins and Eph/Ephrins. PLoS One 11: e0158558, 2016.

72. Zhu XN, Liu XD, Zhuang H, Henkemeyer M, Yang JY and Xu NJ: Amygdala EphB2 signaling regulates glutamatergic neuron maturation and innate fear. J Neurosci 36: 10151-10162, 2016

73. Rodenas-Ruano A, Perez-Pinzon MA, Green EJ, Henkemeyer M and Liebl DJ: Distinct roles for ephrinB3 in the formation and function of hippocampal synapses. Dev Biol 292: 34-45, 2006.

74. Cisse M and Checler F: Eph receptors: New players in Alzheimer's disease pathogenesis. Neurobiol Dis 73: 137-149, 2015.

75. Kalo MS and Pasquale EB: Signal transfer by eph receptors. Cell Tissue Res 298: 1-9, 1999.

76. Zhou XL, Zhang CJ, Wang Y, Wang M, Sun LH, Yu LN, Cao JL and Yan M: EphrinB-EphB signaling regulates spinal pain processing via PKCgamma. Neuroscience 307: 64-72, 2015. 
77. Dalva MB, Takasu MA, Lin MZ, Shamah SM, Hu L, Gale NW and Greenberg ME: EphB receptors interact with NMDA receptors and regulate excitatory synapse formation. Cell 103: 945-956, 2000

78. Grunwald IC, Korte M, Wolfer D, Wilkinson GA, Unsicker K, Lipp HP, Bonhoeffer T and Klein R: Kinase-independent requirement of EphB2 receptors in hippocampal synaptic plasticity. Neuron 32: 1027-1040, 2001

79. Armstrong JN, Saganich MJ, Xu NJ, Henkemeyer M, Heinemann SF and Contractor A: B-ephrin reverse signaling is required for NMDA-independent long-term potentiation of mossy fibers in the hippocampus. J Neurosci 26: 3474-3481, 2006.

80. Lim BK, Matsuda N and Poo MM: Ephrin-B reverse signaling promotes structural and functional synaptic maturation in vivo. Nat Neurosci 11: 160-169, 2008.

81. Filosa A, Paixão S, Honsek SD, Carmona MA, Becker L, Feddersen B, Gaitanos L, Rudhard Y, Schoepfer R and Klopstock T: Neuron-glia communication via EphA4/ephrin-A3 modulates LTP through glial glutamate transport. Nat Neurosci 12: 1285-1292, 2009.

82. Carmona MA, Murai KK, Wang L, Roberts AJ and Pasquale EB: Glial ephrin-A3 regulates hippocampal dendritic spine morphology and glutamate transport. Proc Natl Acad Sci USA 106: 12524-12529, 2009.

83. Battaglia AA, Sehayek K, Grist J, McMahon SB and Gavazzi I: EphB receptors and ephrin-B ligands regulate spinal sensory connectivity and modulate pain processing. Nat Neurosci 6 : 339-340, 2003

84. Song XJ, Cao JL, Li HC, Zheng JH, Song XS and Xiong LZ: Upregulation and redistribution of ephrinB and EphB receptor in dorsal root ganglion and spinal dorsal horn neurons after peripheral nerve injury and dorsal rhizotomy. Eur J Pain 12: 1031-1039, 2008.

85. Slack S, Battaglia A, Cibert-Goton V and Gavazzi I: EphrinB2 induces tyrosine phosphorylation of NR2B via Src-family kinases during inflammatory hyperalgesia. Neuroscience 156 $175-183,2008$.

86. Ruan JP, Zhang HX, Lu XF, Liu YP and Cao JL: EphrinBs/EphBs signaling is involved in modulation of spinal nociceptive processing through a mitogen-activated protein kinases-dependent mechanism. Anesthesiology 112: 1234-1249, 2010.

87. Yu LN, Zhou XL, Yu J, Huang H, Jiang LS, Zhang FJ, Cao JL and Yan M: PI3K contributed to modulation of spinal nociceptive information related to ephrinBs/EphBs. PLoS One 7: e40930, 2012.

88. Laussu J, Khuong A, Gautrais J and Davy A: Beyond boundaries-Eph:ephrin signaling in neurogenesis. Cell Adh Migr 8: 349-359, 2014.

89. Aoki M, Yamashita T and Tohyama M: EphA receptors direct the differentiation of mammalian neural precursor cells through a mitogen-activated protein kinase-dependent pathway. J Biol Chem 279: 32643-32650, 2004.

90. Ricard J, Salinas J, Garcia L and Liebl DJ: EphrinB3 regulates cell proliferation and survival in adult neurogenesis. Mol Cell Neurosci 31: 713-722, 2006.

91. Theus MH, Ricard J, Bethea JR and Liebl DJ: EphB3 limits the expansion of neural progenitor cells in the subventricular zone by regulating $\mathrm{p} 53$ during homeostasis and following traumatic brain injury. Stem Cells 28: 1231-1242, 2010.

92. del Valle K, Theus MH, Bethea JR, Liebl DJ and Ricard J: Neural progenitors proliferation is inhibited by EphB3 in the developing subventricular zone. Int J Dev Neurosci 29: 9-14, 2011.

93. Baumann G, Travieso L, Liebl DJ and Theus MH: Pronounced hypoxia in the subventricular zone following traumatic brain injury and the neural stem/progenitor cell response. Exp Biol Med (Maywood) 238: 830-841, 2013.

94. Khodosevich K, Watanabe Y and Monyer H: EphA4 preserves postnatal and adult neural stem cells in an undifferentiated state in vivo. J Cell Sci 124: 1268-1279, 2011.

95. Ottone C, Krusche B, Whitby A, Clements M, Quadrato G, Pitulescu ME, Adams RH and Parrinello S: Direct cell-cell contact with the vascular niche maintains quiescent neural stem cells. Nat Cell Biol 16: 1045-1056, 2014.

96. Zhou N, Zhao WD, Liu DX, Liang Y, Fang WG, Li B and Chen YH: Inactivation of EphA2 promotes tight junction formation and impairs angiogenesis in brain endothelial cells. Microvasc Res 82: 113-121, 2011.
97. Hassan-Mohamed I, Giorgio C, Incerti M, Russo S, Pala D, Pasquale EB, Zanotti I, Vicini P, Barocelli E, Rivara S, et al: UniPR129 is a competitive small molecule Eph-ephrin antagonist blocking in vitro angiogenesis at low micromolar concentrations. Br J Pharmacol 171: 5195-5208, 2014.

98. Wiedemann E, Jellinghaus S, Ende G, Augstein A, Sczech R, Wielockx B, Weinert S, Strasser RH and Poitz DM: Regulation of endothelial migration and proliferation by ephrin-A1. Cell Signal 29: 84-95, 2017

99. Miranda JD, White LA, Marcillo AE, Willson CA, Jagid J and Whittemore SR: Induction of Eph B3 after spinal cord injury. Exp Neurol 156: 218-222, 1999.

100. Moreno-Flores MT and Wandosell F: Up-regulation of Eph tyrosine kinase receptors after excitotoxic injury in adult hippocampus. Neuroscience 91: 193-201, 1999.

101. Rodger J, Lindsey KA, Leaver SG, King CE, Dunlop SA and Beazley LD: Expression of ephrin-A2 in the superior colliculus and EphA5 in the retina following optic nerve section in adult rat. Eur J Neurosci 14: 1929-1936, 2001.

102. Willson CA, Irizarry-Ramírez M, Gaskins HE, Cruz-Orengo L, Figueroa JD, Whittemore SR and Miranda JD: Upregulation of EphA receptor expression in the injured adult rat spinal cord. Cell Transplant 11: 229-239, 2002.

103. Bundesen LQ, Scheel TA, Bregman BS and Kromer LF: Ephrin-B2 and EphB2 regulation of astrocyte-meningeal fibroblast interactions in response to spinal cord lesions in adult rats. J Neurosci 23: 7789-7800, 2003.

104. del Zoppo GJ: Stroke and neurovascular protection. N Engl J Med 354: 553-555, 2006

105. Ren Z, Chen X, Yang J, Kress BT, Tong J, Liu H, Takano T, Zhao $\mathrm{Y}$ and Nedergaard M: Improved axonal regeneration after spinal cord injury in mice with conditional deletion of ephrin B2 under the GFAP promoter. Neuroscience 241: 89-99, 2013.

106. Pasquale EB: Eph-ephrin bidirectional signaling in physiology and disease. Cell 133: 38-52, 2008.

107. Lukes A, Mun-Bryce S, Lukes M and Rosenberg GA: Extracellular matrix degradation by metalloproteinases and central nervous system diseases. Mol Neurobiol 19: 267-284, 1999.

108. Bunge RP, Puckett WR and Hiester ED: Observations on the pathology of several types of human spinal cord injury, with emphasis on the astrocyte response to penetrating injuries. Adv Neurol 72: 305-315, 1997

109. Fawcett JW and Asher RA: The glial scar and central nervous system repair. Brain Res Bull 49: 377-391, 1999.

110. Dawson MR, Levine JM and Reynolds R: NG2-expressing cells in the central nervous system: are they oligodendroglial progenitors? J Neurosci Res 61: 471-479, 2000.

111. Song I and Dityatev A: Crosstalk between glia, extracellular matrix and neurons. Brain Res Bull, S0361-9230, 2017.

112. Schnell L, Fearn S, Klassen H, Schwab ME and Perry VH: Acute inflammatory responses to mechanical lesions in the CNS: differences between brain and spinal cord. Eur J Neurosci 11: 3648-3658, 1999.

113. McGraw J, Hiebert GW and Steeves JD: Modulating astrogliosis after neurotrauma. J Neurosci Res 63: 109-115, 2001

114. Xie M, Yi C, Luo X, Xu S, Yu Z, Tang Y, Zhu W, Du Y, Jia L and Zhang Q: Glial gap junctional communication involvement in hippocampal damage after middle cerebral artery occlusion. Ann Neurol 70: 121-132, 2011.

115. Stichel CC and Muller HW: The CNS lesion scar: New vistas on an old regeneration barrier. Cell Tissue Res 294: 1-9, 1998.

116. Bush TG, Puvanachandra N, Horner CH, Polito A, Ostenfeld T, Svendsen CN, Mucke L, Johnson MH and Sofroniew MV: Leukocyte infiltration, neuronal degeneration, and neurite outgrowth after ablation of scar-forming, reactive astrocytes in adult transgenic mice. Neuron 23: 297-308, 1999.

117. Faulkner JR, Herrmann JE, Woo MJ, Tansey KE, Doan NB and Sofroniew MV: Reactive astrocytes protect tissue and preserve function after spinal cord injury. J Neurosci 24: 2143-2155, 2004.

118. Jakeman LB and Reier PJ: Axonal projections between fetal spinal cord transplants and the adult rat spinal cord: A neuroanatomical tracing study of local interactions. J Comp Neurol 307: 311-334, 1991

119. Fernandez-Klett F and Priller J: The fibrotic scar in neurological disorders. Brain Pathol 24: 404-413, 2014.

120. Joly S, Jordi N, Schwab ME and Pernet V: The Ephrin receptor EphA4 restricts axonal sprouting and enhances branching in the injured mouse optic nerve. Eur J Neurosci 40: 3021-3031, 2014. 
121. Goldshmit Y, Spanevello MD, Tajouri S, Li L, Rogers F, Pearse M, Galea M, Bartlett PF, Boyd AW and Turnley AM EphA4 blockers promote axonal regeneration and functional recovery following spinal cord injury in mice. PLos One 6 : e24636, 2011.

122. Choi DW: Excitotoxic cell death. J Neurobiol 23: 1261-1276, 1992.

123. Yang J, Luo X, Huang X, Ning Q, Xie M and Wang W: Ephrin-A3 reverse signaling regulates hippocampal neuronal damage and astrocytic glutamate transport after transient global ischemia. J Neurochem 131: 383-394, 2014.

124. Nikolakopoulou AM, Koeppen J, Garcia M, Leish J, Obenaus A and Ethell IM: Astrocytic Ephrin-B1 regulates synapse remodeling following traumatic brain injury. ASN Neuro 8: $1-18,2016$.

125. Zhao C, Deng W and Gage FH: Mechanisms and functional implications of adult neurogenesis. Cell 132: 645-660, 2008.

126. Butti E, Cusimano M,Bacigaluppi M and Martino G: Neurogenic and non-neurogenic functions of endogenous neural stem cells Front Neurosci 8: 92, 2014.

127. Das A, Gupta T, Davla S, Prieto-Godino LL, Diegelmann S, Reddy OV, Raghavan KV, Reichert H, Lovick J and Hartenstein V: Neuroblast lineage-specific origin of the neurons of the Drosophila larval olfactory system. Dev Biol 373: 322-337, 2013.

128. Doeppner TR, Bretschneider E, Doehring M, Segura I, Sentürk A, Acker-Palmer A, Hasan MR, ElAli A, Hermann DM and Bähr M: Enhancement of endogenous neurogenesis in ephrin-B3 deficient mice after transient focal cerebral ischemia. Acta Neuropathol 122: 429-442, 2011.

129. Catchpole T and Henkemeyer M: EphB2 tyrosine kinasedependent forward signaling in migration of neuronal progenitors that populate and form a distinct region of the dentate niche. J Neurosci 31: 11472-11483, 2011.

130. Xing S, He Y, Ling L, Hou Q, Yu J, Zeng J and Pei Z: Blockade of EphB2 enhances neurogenesis in the subventricular zone and improves neurological function after cerebral cortical infarction in hypertensive rats. Brain Res 1230: 237-246, 2008.

131. Yue X, Dreyfus C, Kong TA and Zhou R: A subset of signal transduction pathways is required for hippocampal growth cone collapse induced by ephrin-A5. Dev Neurobiol 68: 1269-1286, 2008.

132. Wegmeyer H, Egea J, Rabe N, Gezelius H, Filosa A, Enjin A, Varoqueaux F, Deininger K, Schnütgen F, Brose N, et al: EphA4-dependent axon guidance is mediated by the RacGAP alpha2-chimaerin. Neuron 55: 756-767, 2007.

133. Shu Y, Xiao B, Wu Q, Liu T, Du Y, Tang H, Chen S, Feng L, Long L and Li Y: The Ephrin-A5/EphA4 interaction modulates neurogenesis and angiogenesis by the p-Akt and p-ERK pathways in a mouse model of TLE. Mol Neurobiol 53: 561-576, 2016.

134. Chen X, Yang H, Zhou X, Zhang L and Lu X: MiR-93 Targeting EphA4 promotes neurite outgrowth from spinal cord neurons. J Mol Neurosci 58: 517-524, 2016.

135. Prestoz L, Chatzopoulou E, Lemkine G, Spassky N, Lebras B, Kagawa T, Ikenaka K, Zalc B and Thomas JL: Control of axonophilic migration of oligodendrocyte precursor cells by Eph-ephrin interaction. Neuron Glia Biol 1: 73-83, 2004.

136. Benson MD, Romero MI, Lush ME, Lu QR, Henkemeyer M and Parada LF: Ephrin-B3 is a myelin-based inhibitor of neurite outgrowth. Proc Natl Acad Sci USA 102: 10694-10699, 2005.

137. Tsenkina Y, Ricard J, Runko E, Quiala-Acosta MM, Mier J and Liebl DJ: EphB3 receptors function as dependence receptors to mediate oligodendrocyte cell death following contusive spinal cord injury. Cell Death Dis 6: e1922, 2015.

138. Lodola A, Giorgio C, Incerti M, Zanotti I and Tognolini M Targeting Eph/ephrin system in cancer therapy. Eur J Med Chem 142: 152-162, 2017.

139. Brantley-Sieders DM, Caughron J, Hicks D, Pozzi A, Ruiz JC and Chen J: EphA2 receptor tyrosine kinase regulates endothelial cell migration and vascular assembly through phosphoinositide 3-kinase-mediated Racl GTPase activation. J Cell Sci 117: 2037-2049, 2004
140. Hassan-Mohamed I, Giorgio C, Incerti M, Russo S, Pala D, Pasquale EB, Zanotti I, Vicini P, Barocelli E, Rivara S, et al: UniPR129 is a competitive small molecule Eph-ephrin antagonist blocking in vitro angiogenesis at low micromolar concentrations. Br J Pharmacol, 171: 5195-5208, 2014.

141. Tae N, Lee S, Kim O, Park J, Na S and Lee JH: Syntenin promotes VEGF-induced VEGFR2 endocytosis and angiogenesis by increasing ephrin-B2 function in endothelial cells. Oncotarget 8: 38886-38901, 2017.

142. Feng L, Shu Y, Wu Q, Liu T, Long H, Yang H, Li Y and Xiao B: EphA4 may contribute to microvessel remodeling in the hippocampal CA1 and CA3 areas in a mouse model of temporal lobe epilepsy. Mol Med Rep 15: 37-46, 2017.

143. Shu Y, Xiao B, Wu Q, Liu T, Du Y, Tang H, Chen S, Feng L, Long L and Li Y: The Ephrin-A5/EphA4 interaction modulates neurogenesis and angiogenesis by the p-Akt and p-ERK pathways in a mouse model of TLE. Mol Neurobiol 53: 561-576, 2016.

144. Cherry JD, Olschowka JA and O'Banion MK: Neuroinflammation and M2 microglia: The good, the bad, and the inflamed. J Neuroinflammation 11: 98, 2014.

145. Chan B and Sukhatme VP: Receptor tyrosine kinase EphA2 mediates thrombin-induced upregulation of ICAM-1 in endothelial cells in vitro. Thromb Res 123: 745-752, 2009.

146. Fang WB, Ireton RC, Zhuang G, Takahashi T, Reynolds A and Chen J: Overexpression of EPHA2 receptor destabilizes adherens junctions via a RhoA-dependent mechanism. J Cell Sci 121: 358-368, 2008.

147. Yuan K, Hong TM, Chen JJ, Tsai WH and Lin MT: Syndecan-1 up-regulated by ephrinB2/EphB4 plays dual roles in inflammatory angiogenesis. Blood 104: 1025-1033, 2004.

148. Shen LL, Zhang LX, Wang LM, Zhou RJ, Yang CZ, Zhang J and Yang PS: Disturbed Expression of EphB4, but Not EphrinB2, inhibited bone regeneration in an in vivo inflammatory microenvironment. Mediators Inflamm 2016: 6430407, 2016.

149. Zhao J, Yuan G, Cendan CM, Nassar MA, Lagerström MC, Kullander K, Gavazzi I and Wood JN: Nociceptor-expressed ephrin-B2 regulates inflammatory and neuropathic pain. Mol Pain 6: 77, 2010.

150. Geng D, Kang L, Su Y, Jia J, Ma J, Li S, Du J and Cui H: Protective effects of EphB2 on Abeta1-42 oligomer-induced neurotoxicity and synaptic NMDA receptor signaling in hippocampal neurons. Neurochem Int 63: 283-290, 2013.

151. Cissé M, Halabisky B, Harris J, Devidze N, Dubal DB, Sun B, Orr A, Lotz G, Kim DH, Hamto P, et al: Reversing EphB2 depletion rescues cognitive functions in Alzheimer model. Nature 469: 47-52, 2011.

152. Henderson JT, Georgiou J, Jia Z, Robertson J, Elowe S, Roder JC and Pawson T: The receptor tyrosine kinase EphB2 regulates NMDA-dependent synaptic function. Neuron 32: 1041-1056, 2001

153. Fu AK, Hung KW, Huang H, Gu S, Shen Y, Cheng EY, Ip FC, Huang X, Fu WY and Ip NY: Blockade of EphA4 signaling ameliorates hippocampal synaptic dysfunctions in mouse models of Alzheimer's disease. Proc Natl Acad Sci USA 111: 9959-9964, 2014

154. Hardiman O, Al-Chalabi A, Chio A, Corr EM, Logroscino G, Robberecht W, Shaw PJ, Simmons Z and van den Berg LH: Amyotrophic lateral sclerosis. Nat Rev Dis Primers 3: 17071, 2017.

155. Tsuda H, Han SM, Yang Y, Tong C, Lin YQ, Mohan K, Haueter C, Zoghbi A, Harati Y, Kwan J, et al: The amyotrophic lateral sclerosis 8 protein VAPB is cleaved, secreted, and acts as a ligand for Eph receptors. Cell 133: 963-977, 2008

156. Van Hoecke A, Schoonaert L, Lemmens R, Timmers M, Staats KA, Laird AS, Peeters E, Philips T, Goris A, Dubois B, et al: EPHA4 is a disease modifier of amyotrophic lateral sclerosis in animal models and in humans. Nat Med 18: 1418-1422, 2012.

This work is licensed under a Creative Commons Attribution-NonCommercial-NoDerivatives 4.0 International (CC BY-NC-ND 4.0) License. 